\title{
Analysis of the characteristics of periodontal curettes used for scaling the roof of the furcation by manual versus digital method
}

\author{
Análise das características de curetas periodontais utilizadas para raspagem \\ em teto de furca pelo método manual versus digital
}

\author{
Larissa Porcaro SALOMÃOa ${ }^{-1}$, Marcela Morgana Teixeira da SILVA ${ }^{a}$ (D), \\ Alessandra Areas e SOUZA ${ }^{a}{ }^{(1)}$, Gabriela Alessandra da Cruz Galhardo CAMARGO ${ }^{\mathrm{a}, \mathrm{b}}$ (1), \\ Eliane Marçon BARROSO ${ }^{\mathbb{C}}$, Elizangela Cruvinel ZUZA ${ }^{\mathrm{a}, \mathrm{b} *}$ (]) \\ aUFF- Universidade Federal Fluminense, Instituto de Saúde de Nova Friburgo, Departamento de Formação Específica, \\ Nova Friburgo, RJ, Brasil \\ bUFF - Universidade Federal Fluminense, Instituto de Saúde de Nova Friburgo, PPGO-ISNF - Programa de Pós- \\ graduação em Odontologia, Nova Friburgo, RJ, Brasil \\ 'UNIFEB - Centro Universitário da Fundação, Faculdade de Odontologia, Departamento de Odontologia, Barretos, SP, \\ Brasil
}

\begin{abstract}
How to cite: Salomão LP, Silva MMT, Souza AA, Camargo GACG, Barroso EM, Zuza EC. Analysis of the characteristics of periodontal curettes used for scaling the roof of the furcation by manual versus digital method. Rev Odontol UNESP. 2021;50:e20210010. https://doi.org/10.1590/1807-2577.01021
\end{abstract}

\begin{abstract}
Resumo
Introdução: 0 tratamento da doença periodontal em dentes multirradiculares com envolvimento de furca tem sido um desafio para os cirurgiões-dentistas, com resultados imprevisíveis. Objetivo: Avaliar as características da ponta ativa de curetas periodontais utilizadas para raspagem do teto de furca, comparando o método manual versus digital. Material e método: Foram avaliadas 42 curetas de Pádua Lima (PL) da marca Millennium ${ }^{\circledR}$ (n=6 para cada modelo): PL 1-2, PL 3-4, PL 5-6, PLW 1-2, PLW 3-4, PLW 5-6 e PLF. Foram mensurados: comprimento total da face coronária (CTc, milímetros, $\mathrm{mm}$ ), comprimento total da face lateral $(\mathrm{CTl}, \mathrm{mm})$, largura da face coronária $(\mathrm{Lc}, \mathrm{mm})$ e largura da face lateral $(\mathrm{Ll}, \mathrm{mm})$. As mensurações foram em duplicata. Resultado: Os resultados mostraram que o peso variou entre as curetas $(p<0,05)$, porém o diâmetro do cabo foi semelhante para todos os instrumentos $(p>0,05)$. Considerando que foram avaliados sete tipos de curetas diferentes, os parâmetros de CTl e Ll se mostraram com diferença estatística para todas as curetas avaliadas (proporção 7:7), com valores maiores para o método do paquímetro em comparação ao software $(\mathrm{p}<0,05)$. Houve diferença estatisticamente significativa entre métodos de avaliação para as medidas de CTc e de Lc $(\mathrm{p}<0,05)$, mostrando que houve uma coincidência de valores na proporção de 4:7 para as mensurações de CTc e de 5:7 para Lc. Conclusão: A comparação entre métodos resultou, em geral, menores valores e maior variação para o método digital, favorecendo, dessa forma, o uso do método manual para a mensuração da ponta ativa de curetas periodontais.
\end{abstract}

Descritores: Doenças periodontais; periodontia; instrumentos odontológicos.

\begin{abstract}
Introduction: The treatment of periodontal disease in multiradicular teeth with furcation involvement is a challenge for dentists, with unpredictable results. Objective: To evaluate the characteristics of the active tip of periodontal curettes used for scaling the furcation roof, comparing the manual versus digital method. Material and method: Forty-two Pádua Lima (PL) curettes of the Millennium ${ }^{\circledR}$ brand ( $\mathrm{n}=6$ for each model) were evaluated: PL 1-2, PL 3-4, PL 5-6, PLW 1-2, PLW 3-4, PLW 5 -6, and PLF. The following were measured: total length of the coronary face (CTc, millimeters, $\mathrm{mm}$ ), total length of the lateral face (CTl, $\mathrm{mm}$ ), width of the coronary face (Lc, $\mathrm{mm}$ ), and width of the lateral face ( $\mathrm{Ll}, \mathrm{mm}$ ). The measurements were performed in duplicate. Result: The results showed that weight varied among the curettes $(p<0.05)$, however the handle diameter was similar for all instruments $(p>0.05)$. Considering that seven different
\end{abstract}


types of curettes were evaluated, the parameters of CTl and Ll showed a statistical difference for all evaluated curettes (7: 7 ratio), with higher values for the caliper method compared to the software $(\mathrm{p}<0.05)$. There was a statistically significant difference between assessment methods for CTc and Lc measurements $(p<0.05)$, showing that there was a coincidence of values in the proportion of $4: 7$ for measurements of CTc and 5:7 for Lc. Conclusion: The comparison between methods generally resulted in lower values and greater variation for the digital method, thus favoring the use of the manual method to measure the active tip of periodontal curettes.

Descriptors: Periodontal diseases; periodontics; dental instruments.

\section{INTRODUCTION}

The treatment of multiradicular teeth with furcation involvement is a challenge for dentists, with unpredictable results. Added to the difficulty of instrumentation in this inter-furcal region due to the anatomical complexity ${ }^{1-4}$, there may also be the presence of cervical enamel projections $^{5}$, interradicular hollow channels ${ }^{6}$, proximity between the roots ${ }^{7}$, root fusion ${ }^{2}$, and enamel pearls ${ }^{8}$.

The height of the root trunk varies in the different furcation entrances in both maxillary and mandibular molars, with the first molar having a smaller root trunk than the second molar. In the maxillary first molar, the mesial, buccal, and distal furcation entrances are located approximately $3.0 \mathrm{~mm}, 3.5 \mathrm{~mm}$, and $5 \mathrm{~mm}$ from the cementoenamel junction (CEJ), respectively. Considering the mandibular molars, the lingual furcation entrance is usually $>4 \mathrm{~mm}$ in relation to the CEJ and the buccal furcation entrance $>3 \mathrm{~mm}$, with an entrance width $<0.75 \mathrm{~mm}$ in the buccal and $>0.75 \mathrm{~mm}$ in the lingual furcation 9 . The heights of the root trunk presented different means in other findings ${ }^{10}$ of maxillary molars, ranging from $4.44 \mathrm{~mm}$ for the mesial furcation entrance, $3.50 \mathrm{~mm}$ for the buccal furcation entrance, and $4.26 \mathrm{~mm}$ for the distal furcation entrance.

The dimensions of the furcation entrances were evaluated by Hou et al. ${ }^{11}$ in maxillary first and second molars of Chinese individuals. The authors evaluated 89 maxillary molars (49 first molars and 40 second molars) and 93 mandibular molars (50 first molars and 43 second molars), noting that the furcation entrances in the maxillary first molars showed an average of $0.74 \mathrm{~mm}$ for the buccal furcation entrance, $0.99 \mathrm{~mm}$ for the distal furcation entrance, and $1.04 \mathrm{~mm}$ for the mesial furcation entrance. The maxillary second molars presented an average of $0.63 \mathrm{~mm}$ for the buccal furcation entrance; $0.67 \mathrm{~mm}$ for the distal furcation entrance, and $0.90 \mathrm{~mm}$ for the mesial furcation entrance. In the mandibular first molars, the mean was $0.88 \mathrm{~mm}$ for the buccal furcation entrance and $0.81 \mathrm{~mm}$ for the lingual furcation entrance. As for the second mandibular molars, the means were, respectively, $0.73 \mathrm{~mm}$ and $0.71 \mathrm{~mm}$ for the buccal and lingual furcation entrances.

It is not only important to know the height of the furcation entrances on the different faces, but also to know the dimensions of the anatomical characteristics of this region. In this context, a study ${ }^{4}$ demonstrated that the lingual and buccal inter-furcal regions were narrower compared to the central portion, proving that there is an anatomical limitation that can clinically compromise the insertion of instruments for periodontal treatment in the furcal region.

Considering the differences between the dimensions of the inter-furcal region of multiradicular teeth, another important aspect to be considered is the size of the blades of periodontal curettes used for periodontal treatment in this region ${ }^{12}$. To facilitate access to different anatomical regions, such as furcation regions, narrow and/or deep pockets, and areas with root concavities, curettes are manufactured with angulation variations in their shaft ${ }^{13}$, however, it is important to consider that the characteristics of the instrument's active tip, such as width and length of the faces, must be evaluated, considering the anatomical limitations of multiradicular teeth. 
Traditionally, in dentistry, the manual method with a caliper has been used for several purposes, in order to measure variables such as linear measurements on radiographs ${ }^{14}$ or even in teeth and periodontal instruments ${ }^{12}$, however, the number of applications (software) available online and free of charge has been growing and gaining prominence in the health area, and this is of great value for professionals who want to adopt an electronic recording system ${ }^{15}$.

A systematic review evaluated the literature on the availability and use of open source dental software ${ }^{16}$, and the analysis revealed that the dental literature presents scarce, incomplete, and low methodological quality information about open source software in dentistry, including image visualization programs. However, some authors point out that a more detailed analysis of free online software could benefit potential practitioners of electronic healthcare systems ${ }^{15}$. Thus, the aim of the current study was to evaluate the characteristics of the active tip of periodontal curettes used for scaling the furcation roof, comparing the manual versus digital method.

\section{METHODOLOGY}

The present work is a cross-sectional observational study, developed in the multidisciplinary laboratory of the Fluminense Federal University (UFF) of the Nova Friburgo Health Institute (ISNF)

\section{Study Groups}

Forty-two periodontal curettes, model Pádua Lima (PL), Millennium ${ }^{\circledR}$ brand (Golgran Ind Com Instr Odontológico, São Caetano do Sul, Brazil) were evaluated, of seven different models, as follows: PL 1-2 ( $n=6)$, PL 3-4 ( $n=6)$, PL 5-6 ( $n=6)$, PLW 1-2 ( $n=6)$, PLW 3-4 ( $n=6)$, PLW 5-6 ( $n=6)$, and PLF $(n=6)$. The curettes were required to be from different manufacturing batches.

The following instrument characteristics were evaluated: weight (W, grams), handle diameter (D, millimeters, $\mathrm{mm}$ ), total length of active blade on the coronary face (CTc, $\mathrm{mm}$ ), total length of active blade on the lateral face ( $\mathrm{CTl}, \mathrm{mm}$ ), width of the coronary face in the middle portion of the active tip (Lc, mm), and width of the lateral face in the middle portion of the active tip ( $\mathrm{Ll}, \mathrm{mm}$ ). For the measurements of $\mathrm{W}$ and $\mathrm{D}$, the methodology of Penteado et al. ${ }^{17}$ was followed and, for the measurements of CTc, CTl, Lc, and Ll the methodology of Dantas et al.12

D was evaluated only using the caliper. The measurements of CTc, CTl, Lc, and Ll were performed using two different methods: 1) Manual: precision digital caliper (Mitutoyo®, Santo Amaro, São Paulo); 2) Digital: ImageJ software ${ }^{\circledR}$ (National Institutes of Health, Bethesda, USA), and the measures were compared for the evaluation of the proposed methods.

\section{Manual Method}

According to the recommendation of Tahim et al. ${ }^{18}$, the caliper was returned to the initial position (zero) for each measurement, in order to avoid a biased reading. Measurements were performed with the visual aid of a binocular magnifying glass attached to the examiner's head (Bio-Art Equipamentos Odontológicos, São Carlos, Brazil). The curettes were positioned over a white paper background, and the examiner kept their arms supported on a bench with a firm and flat surface, to avoid slipping and changes in position that could interfere with the analysis. The measurements were performed in duplicate, with means and standard deviations being calculated. 


\section{Digital Method}

All curettes were photographed on their coronary and lateral sides, next to a millimeter endodontic ruler, to standardize the measurement scale (in millimeters). The photos were taken in a standardized way, with a Sony Cybershot DSC-HX1 machine (Fábrica Sony Brasil Ltda, Manaus, Brazil), positioned at $90^{\circ}$ in relation to the curettes, at a distance of $15 \mathrm{~cm}$, with an approximate zoom of 2,5x. The photo file was opened in the Image ${ }^{\circledR}$ program, selecting "File" and "Open". Next, the endodontic rule was measured linearly up to $10 \mathrm{~mm}$, and the measure was standardized as the known measure in "Analyze" and "Set scale" (in $10 \mathrm{~mm}$ ). Subsequently, with the linear tool again, the coronary and lateral faces of the curettes were measured separately. To visualize the obtained measure, we clicked on "Analyze" and "Measure". The result was expressed in length (in millimeters) as "Length". The measurements were performed in duplicate and means and standard deviations were calculated.

\section{Intra-examiner Calibration}

A single researcher (LPS) was trained and calibrated, by an experienced researcher, (ECZ) to perform all measurements. The intra-examiner calibration used six curettes (PL 1-2; PL 3-4; PL 5-6; PLW 1-2; PLW 3-4; PLW 5-6, and PLF), one of each model, considering CTc, CTl, Lc, and Ll. As the curettes had a double tip, an overall mean was considered. Measurements were taken at two different times, with a one-week interval. For the manual method, the intraclass correlation (IC) for continuous data showed excellent replicability (IC=0.9995; $\mathrm{p}<0.0001$ ), as well as for calibration of the digital method ( $\mathrm{IC}=0.9978$; $\mathrm{p}<0.0001$ ). When comparing the manual method versus the digital method, considering the same measurement parameters for $\mathrm{CTc}, \mathrm{CTl}, \mathrm{Lc}$, and $\mathrm{Ll}$, the replicability was also excellent $(\mathrm{IC}=0.9932 ; \mathrm{p}<0.0001)$. To verify the $\mathrm{IC}$, the BioEstat 5.0 program was used (Belém, PA, Brazil).

\section{Weight}

The curettes were weighed on a precision digital scale, model AD5000 (Marte Científica ${ }^{\circledR}$, Santa Rita do Sapucaí, Minas Gerais, Brazil), supported on a flat surface. Following the methodology proposed by Penteado et al. ${ }^{17}$, each curette was placed gently on the scale and the value was noted only after the numbers on the display had stabilized. This procedure was performed twice for each periodontal curette and means were calculated for each instrument.

\section{Diameter of the Handle}

The instrument handle diameter was measured with a precision caliper (Mitutoyo®, Santo Amaro, São Paulo), considering the central portion of each instrument. Measurements were taken twice to calculate means.

\section{CTc, CTI, Lc, and LI Measurements}

The CTc and CTl length was considered as a linear measure, from the beginning of the active tip to the end, on the coronary (CTc) and lateral (CTl) faces, respectively ${ }^{12}$. The width for Lc was measured in the middle portion of the instrument, from the cutting blade from one side to the other, linearly, with the cutting blade being formed by the coronary and lateral/apical sides. Likewise, $\mathrm{Ll}$ was measured in the middle portion of the face, linearly, from the cutting blade to the 
end of the lateral face, against the back of the instrument. Measurements were taken twice to calculate means. All measurements were performed using both the manual method (Figure 1 A-D) and the digital method for comparison between methods.
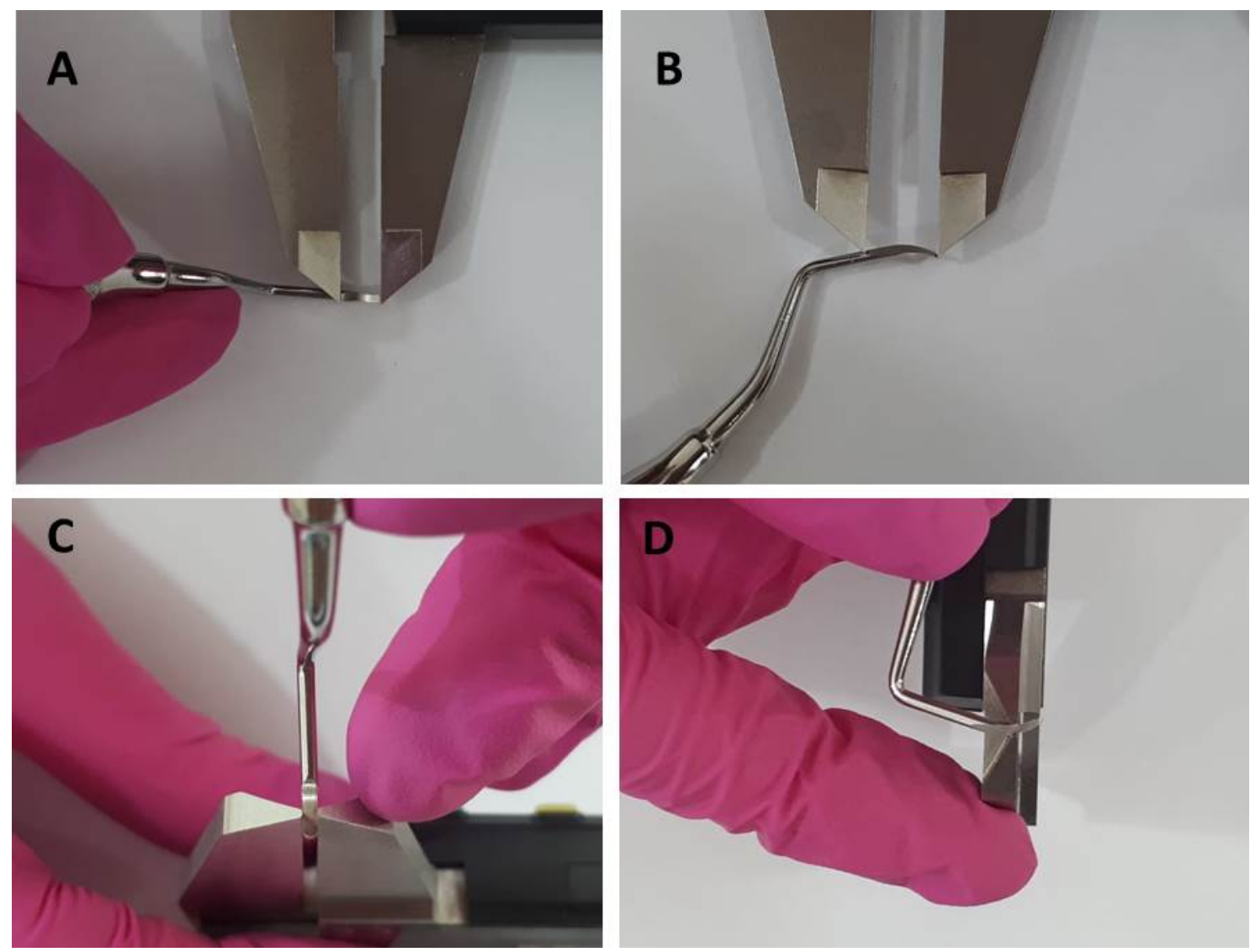

Figure 1. (A) Total length of active blade on the coronary face (CTc, mm); (B) Total length of active blade on the lateral face (CTI, mm); (C) Width of the coronary face in the middle portion of the active tip (Lc, $\mathrm{mm}$ );

(D) Width of the lateral face in the middle portion of the active tip (LI, $\mathrm{mm}$ ).

\section{Statistical Analysis}

From the measurements obtained for each parameter, means and standard deviations were calculated. Data were analyzed for normality using the Shapiro-Wilk test. Comparisons among groups of curettes and between analysis methods were performed using the Kruskal-Wallis test (if not parametric) or one-way ANOVA followed by Tukey (if parametric), considering a significance level of 5\%. The BioEstat 5.0® program (Mamirauá, AM, Brazil) was used for the analysis.

\section{RESULT}

The weight (g) of the handle varied among the periodontal curettes evaluated, and, in general, the PLW 1-2, PLW 3-4, PLW 5-6, and PLF curettes were heavier than the PL 1-2, PL 3-4, and PL 56 curettes $(\mathrm{p}<0,05)$. The handle diameter $(\mathrm{mm})$ was similar for all curettes, with no statistically significant differences between measurements ( $p>0.05)$ (Figure 2). 


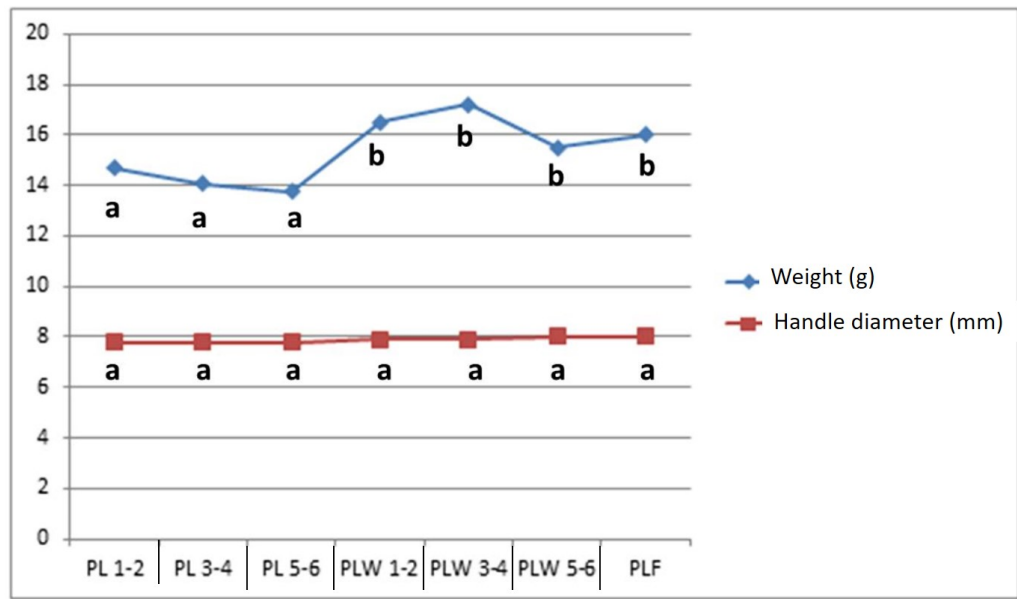

Figure 2. Variation in means among curettes considering the weight $(\mathrm{g})$ and diameter of the handle $(\mathrm{mm})$. ${ }^{a, b}$ Different letters within the same line indicate a statistically significant difference among curettes in relation to the evaluated parameter (Non-parametric data; Kruskal-Wallis test, followed by Dunn $p<0.05$ ).

The comparison between measurement methods resulted, in general, in higher values for the manual method compared to the digital method for the majority of parameters. The manual vs. digital methods for measuring the parameters of $\mathrm{CTl}$ and $\mathrm{Ll}$ showed statistical difference for all curettes evaluated (PL 1-2; PL 3-4; PL 5-6; PLW 1-2; PLW 3-4; PLW 5-6, and PLF), with significantly higher values for the caliper method $(\mathrm{P}<0.05)$. CTc measurements showed similar values of measurements with no statistical difference for PL 3-4, PL 5-6, PLW 5-6, and PLF ( $p>0.05$ ), but with a significant difference for PL 1-2, PLW 1-2, and PLW 3-4 ( $p<0.05)$; thus, considering that seven different types of curettes were evaluated, there was a coincidence of values in the proportion of 4:7 for the measurements of CTc and 5:7 for the Lc parameter. For Lc there was a statistical agreement for PL 1-2, PL 5-6, PLW 1-2, PLW 3-4, and PLF ( $p>0.05)$ and a statistical difference for PL 3-4 and PLW 5-6 (p<0.05) (Figure 3; Table 1).
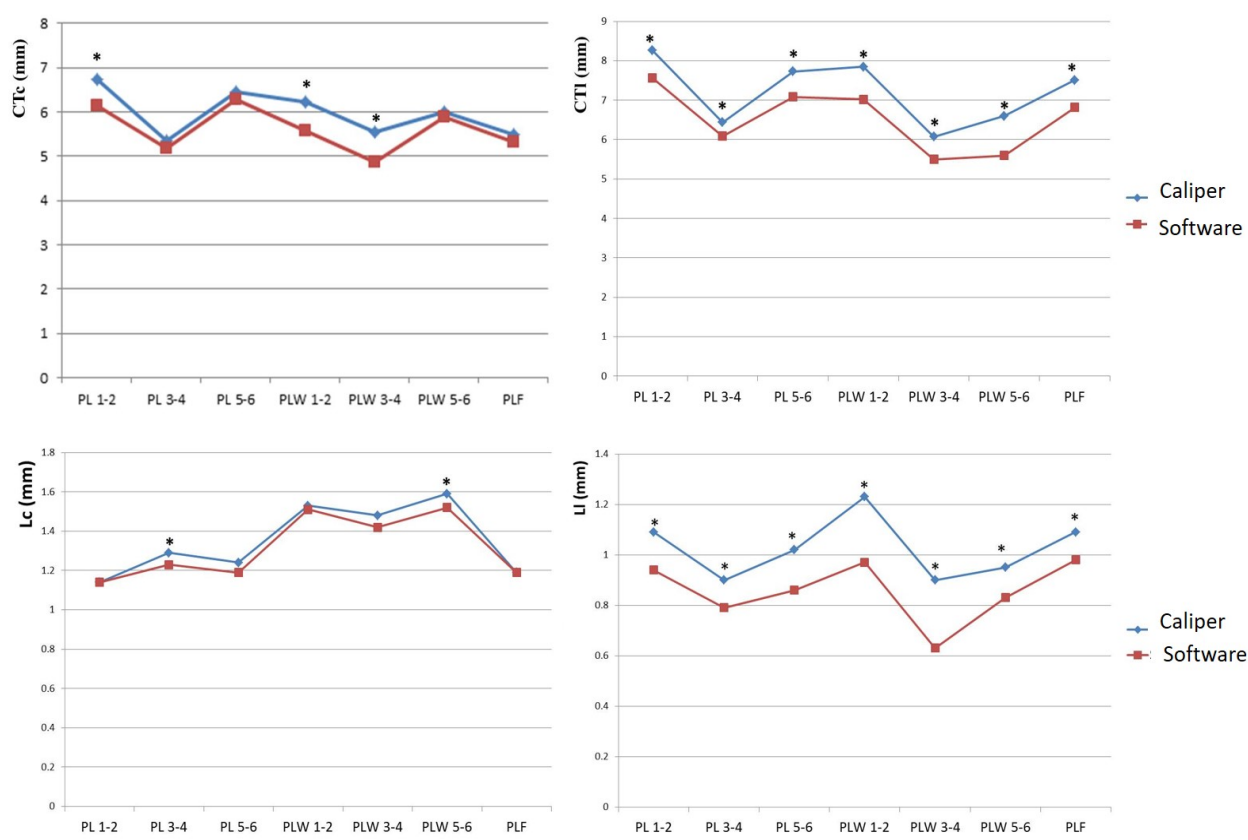

Figure 3. Illustration of mean variation among curettes considering total coronary length (CTc), total lateral length (CTI), coronary width (LC), and lateral width (LI). * Asterisk indicates difference between caliper vs. software measurement methods among curettes for each parameter evaluated in CTc, CTI, Lc, and LI (Wilcoxon for non-parametric data and t test for parametric data; $p<0.05$ ). 
Table 1. Comparison between caliper vs. software for measurements of CTc (total coronary length), CTI (total lateral length), Lc (coronary width), and LI (coronary width).

\begin{tabular}{|c|c|c|c|c|}
\hline Curettes & CTc & CTI & LC & Ll \\
\hline \multicolumn{5}{|l|}{ PL 1-2 } \\
\hline Caliper & $6.73 \pm 0.16 \mathrm{a}$ & $8.27 \pm 0.29$ a & $1.14 \pm 0.04 \mathrm{a}$ & $1.09 \pm 0.06 \mathrm{a}$ \\
\hline \multicolumn{5}{|l|}{ PL 3-4 } \\
\hline Caliper & $5.34 \pm 0.29 a$ & $6.44 \pm 0.21$ a & $1.29 \pm 0.04 \mathrm{a}$ & $0.90 \pm 0.05$ a \\
\hline \multicolumn{5}{|l|}{ PL 5-6 } \\
\hline Caliper & $6.44 \pm 0.28{ }^{a}$ & $7.73 \pm 0.29 \mathrm{a}$ & $1.24 \pm 0.03 \mathrm{a}$ & $1.02 \pm 0.10$ a \\
\hline Software & $6.28 \pm 0.32$ a & $7.08 \pm 0.34 b$ & $1.19 \pm 0.05$ a & $0.86 \pm 0.03 b$ \\
\hline \multicolumn{5}{|l|}{ PLW 1-2 } \\
\hline Caliper & $6.22 \pm 0.52 \mathrm{a}$ & $7.85 \pm 0.48 \mathrm{a}$ & $1.53 \pm 0.11^{a}$ & $1.23 \pm 0.12$ a \\
\hline Software & $5.57 \pm 0.64 \mathrm{~b}$ & $7.02 \pm 0.45 b$ & $1.51 \pm 0.07$ a & $0.97 \pm 0.16^{b}$ \\
\hline \multicolumn{5}{|l|}{ PLW 3-4 } \\
\hline Caliper & $5.56 \pm 1.10^{a}$ & $6.07 \pm 0.20^{a}$ & $1.48 \pm 0.06^{a}$ & $0.90 \pm 0.03$ a \\
\hline Software & $4.86 \pm 0.18^{b}$ & $5.50 \pm 0.31 b$ & $1.42 \pm 0.07$ a & $0.63 \pm 0.08 \mathrm{~b}$ \\
\hline \multicolumn{5}{|l|}{ PLW 5-6 } \\
\hline Caliper & $6.0 \pm 0.64 \mathrm{a}$ & $6.6 \pm 0.22 a$ & $1.59 \pm 0.06^{a}$ & $0.95 \pm 0.05$ a \\
\hline \multicolumn{5}{|l|}{ PLF } \\
\hline Caliper & $5.5 \pm 0.44 \mathrm{a}$ & $7.51 \pm 0.36^{a}$ & $1.19 \pm 0.06^{a}$ & $1.09 \pm 0.06^{\mathrm{a}}$ \\
\hline Software & $5.31 \pm 0.53 \mathrm{a}$ & $6.82 \pm 0.24 b$ & $1.19 \pm 0.05^{a}$ & $0.98 \pm 0.06^{b}$ \\
\hline
\end{tabular}

a,bDifferent letters indicate difference between the caliper vs. software measurement methods in each evaluated parameter (Wilcoxon for non-parametric data and t-test for parametric data; $\mathrm{p}<0.05$ ).

\section{DISCUSSION}

The morphology of the furcation region in molar teeth is an important topic for clinical practice, since furcation involvement is one of the main problems related to the success of periodontal treatment in multiradicular teeth $1,3,4,11$. The height of the root trunk varies in different furcation entrances and is controversial in different studies. While some findings indicate that the mesial furcation entrance of the maxillary first molars and buccal furcation entrance of the mandibular molars may be primarily affected by periodontal disease due to the lower height of the root trunk on these sides ${ }^{9}$, other findings point to vestibular furcation entrance as having the highest risk of involvement ${ }^{10}$.

For treatment planning and prognosis, the size of periodontal curettes plays an important role, as it is necessary for the blade to have an adequate width to reach this region, without causing damage to periodontal tissues, in addition to having resistance to fracture, to perform the treatment effectively ${ }^{19}$. The dimensions of the active tip of specific periodontal curettes for scaling in the furcation region were analyzed in the present study, comparing the manual and digital methods. Regardless of the method used, it was possible to verify that there was a variation of from 1.14 to $1.59 \mathrm{~mm}$ in the coronary width of the active tip of the analyzed curettes (Figure 3; Table1), which demonstrates a clinical limitation in the insertion of adequate instruments in this area for periodontal treatment, considering, for example, the buccal furcation entrance width < $0.75 \mathrm{~mm}$ and lingual furcation entrance $>0.75 \mathrm{~mm}$ in the mandibular molars ${ }^{9}$. The study by Goulart et al. ${ }^{4}$ also highlighted that the lingual and buccal inter-furcation regions were narrower compared to the central portion of mandibular first molars.

Another study that evaluated molar teeth ${ }^{11}$ showed a mean furcation entrance width of $0.74 \mathrm{~mm}$ for the buccal furcation entrance, $0.99 \mathrm{~mm}$ for the distal furcation entrance, and $1.04 \mathrm{~mm}$ for the mesial furcation entrance of the maxillary first molars, and $0.63 \mathrm{~mm}$ for the 
buccal furcation entrance, $0.67 \mathrm{~mm}$ for the distal furcation entrance, and $0.90 \mathrm{~mm}$ for the mesial furcation entrance of the maxillary second molars. When the mandibular first molars were evaluated, the mean was $0.88 \mathrm{~mm}$ for the buccal furcation entrance and $0.81 \mathrm{~mm}$ for the lingual furcation entrance, while the second molars showed greater narrowing of the furcation entrance, with means of $0.73 \mathrm{~mm}$ and $0.71 \mathrm{~mm}$ for the buccal and lingual furcation entrances, respectively. These findings prove that the periodontal curettes evaluated have greater widths (1.14 to $1.59 \mathrm{~mm}$; Figure 3 and Table 1) than the furcation entrances, which limits the instrument's entry into the region and can directly interfere with the treatment result. In these cases, a good alternative would be the use of ultrasonic tips, which have greater tapering at the active end, and some findings also showed that the surface roughness of the tooth root treated with piezoelectric ultrasonic devices was lower when compared to manual instrumentation with curettes ${ }^{20}$.

In the present study, the manual versus digital method for measuring the CTl and $\mathrm{Ll}$ parameters presented a statistical difference for all curettes evaluated (PL 1-2; PL 3-4; PL 5-6; PLW 1-2; PLW 3-4; PLW 5-6; and PLF), with significantly higher values for the caliper method $(\mathrm{P}<0.05$; Figure 3 and Table 1). Based on the data obtained in this study, it can be observed that there was a difference between the manual and digital methods. The evaluation with the digital method led to greater variation between the measurements of the curettes, thus, the results demonstrate that the caliper method seems to have a positive potential when compared to the digital method. This result can be explained by the fact that the caliper allows better precision in the delimitation of the active tip of periodontal curettes, when compared to the digital method, since the visualization of the instrument by the caliper method is more assertive, considering that curettes have a three-dimensional structure with different faces and curvature at the active tip. The proximity of the instrument to the examiner in the caliper method allows, with the aid of a binocular magnifying glass, better accuracy of the analyzed points and a reduction in measurement deviations, which provides more assertive results. Furthermore, the digital method can facilitate parallax errors, that is, an error that is caused by an optical deviation in the observer's angle of view, which does not occur with the manual method. This deviation directly influences the results, since the dimension of the blades can be changed, which may explain the greater variation in the dimensions of the blades obtained by the digital method.

The present study found that the comparison between measurement methods resulted, in general, in higher values for the manual method compared to the digital method (Figure 3 and Table 1). This finding emphasizes the importance of the digital precision caliper, still being the most appropriate resource of choice to carry out analyses of the dimensions of periodontal curettes and other instruments that have three-dimensional shapes and/or curvatures. This fact does not rule out the importance and ease of implementing the use of digital programs to be applied in the health area ${ }^{15}$. Thus, it is important to know the characteristics of the product to be evaluated and the measurements obtained, considering that these imaging programs, in general, work with linear measurements. The study of Fontão et al. ${ }^{14}$ comparatively evaluated the use of digital (software) and manual (caliper) methods for the analysis of panoramic radiographs with linear distance measurement of anatomical distances, demonstrating that there were no significant differences between manual and digital measurements and that the digital method can be used successfully for radiographic analysis.

It is noteworthy that no study is definitive and that possible biases should be considered, such as the influence of the operator in the analyses, the use of a single type of periodontal curette and a commercial brand. It is suggested that further studies be carried out with different models of periodontal curettes and comparisons between brands, in order to better elucidate whether the manual method can be replaced by the digital method for the analysis of these dental instruments. It is noteworthy that the tendency of the manual method to be replaced by the digital method is great and that it is necessary to carefully assess the individualities and characteristics of each product to be evaluated. 


\section{CONCLUSION}

It can be concluded that the comparison between methods resulted, in general, in lower values and greater variation for the digital method, thus favoring the use of the manual method for measuring periodontal curettes.

\section{ACKNOWLEDGEMENTS}

Acknowledgements to PIBIC (Institutional Program for Scientific Initiation Scholarships) of the Federal Fluminense University (UFF) for providing financial support to Larissa Porcaro Salomão (IC 190223) and Marcela Morgana Teixeira da Silva (IC 180688) and to the company Golgran Ind Com Instr Odontológicos for the loan of the periodontal instruments evaluated in the study.

\section{REFERENCES}

1. Chiu BM, Zee KY, Corbet EF, Holmgren CJ. Periodontal implications of furcation entrance dimensions in chinese first permanent molars. J Periodontol. 1991 May;62(5):308-11.

http://dx.doi.org/10.1902/jop.1991.62.5.308.

2. Hou G-L, Tsai C-C. The morphology of root fusion in Chinese adults (I). Grades, types, location and distribution. J Clin Periodontol. 1994 Apr;21(4):260-4. http://dx.doi.org/10.1111/j.1600051X.1994.tb00315.x.

3. Santana RB, Uzel MI, Gusman H, Gunaydin Y, Jones JA, Leone CW. Morphometric analysis of the furcation anatomy of mandibular molars. J Periodontol. 2004 Jun;75(6):824-9. http://dx.doi.org/10.1902/jop.2004.75.6.824.

4. Goulart RS, Bruniera JFB, Ribeiro GM, Oliveira JS, Marcaccini AM, Silva Sousa YTC. Avaliação da anatomia das áreas de furca, pré-furca e inter-furca de primeiros molares inferiores, por meio de microCT. Braz Oral Res. 2016;30(Suppl 1):234.

5. Hou G-L, Tsai C-C. Relationship between periodontal furcation involvement and molar cervical enamel projections. J Periodontol. 1987 Oct;58(10):715-21. http://dx.doi.org/10.1902/jop.1987.58.10.715.

6. Zuza EP, Toledo BEC, Hetem S, Spolidorio LC, Mendes AJD, Rosetti EP. Prevalence of different types of accessory canals in the furcation area of third molars. J Periodontol. 2006 Oct;77(10):1755-61. http://dx.doi.org/10.1902/jop.2006.060112.

7. Kramer GM. A consideration of root proximity. Int J Periodontics Restorative Dent. 1987;7(6):8-33.

8. Risnes S. The prevalence, location, and size of enamel pearls on human molars. Scand J Dent Res. 1974;82(6):403-12. http://dx.doi.org/10.1111/j.1600-0722.1974.tb00394.x.

9. Lang NP, Lindhe J. Tratado de periodontia clínica e implantodontia oral. Rio de Janeiro: Guanabara Koogan; 2018.

10. Porciúncula HF, Zuza EP, da Porciúncula MM, de Toledo BEC, Mendes AJD. Root trunk height as a risk factor for periodontal furcation involvement in maxillary first molars: an in vitro study. J Int Acad Periodontol. 2007 Jul;9(3):89-95.

11. Hou G-L, Chen S-F, Wu Y-M, Tsai C-C. The topography of the furcation entrance in Chinese molars: Furcation entrance dimensions. J Clin Periodontol. 1994 Aug;21(7):451-6. http://dx.doi.org/10.1111/j.1600-051X.1994.tb00407.x.

12. Dantas CDF, Cavassim R, Pinto SCS, Cirelli JÁ, Sampaio JEC, Bolini PDA. Dimensões das furcas de primeiros pré-molares superiores e sua relação com curetas periodontais. PerioNews. [Internet]. 2010 [cited 2021 Feb 25];4(4):355-62. Available from: http://hdl.handle.net/11449/125831 
13. Nagy RJ, Otomo-Corgel J, Stambaugh R. The Effectiveness of scaling and root planing with curets designed for deep pockets. J Periodontol. 1992 Dec;63(12):954-9. http://dx.doi.org/10.1902/jop.1992.63.12.954.

14. Fontão FNGK, Chinellato LEM, Bullen IRF, Dezotti MSG. Medidas lineares em radiografias panorâmicas digitalizadas, fornecidas por programa de imagem para planejamento na implantodontia: correlação e análise crítica. Rev Salusvita. 2006;25(2):165-83.

15. Kiah MLM, Haiqi A, Zaidan BB, Zaidan AA. Open source EMR software: profiling, insights and hands-on analysis. Comput Methods Programs Biomed. 2014 Nov;117(2):360-82. http://dx.doi.org/10.1016/j.cmpb.2014.07.002.

16. Chruściel-Nogalska M, Smektała T, Tutak M, Sporniak-Tutak K, Olszewski R. Open-source software in dentistry: a systematic review. Int J Technol Assess Health Care. 2017 Jan;33(4):487-93. http://dx.doi.org/10.1017/S0266462317000708.

17. Penteado LAM, Awabdi TWM, Auto VC, Rodrigues EDO, Oliveira DP, Santos NB. Avaliação da padronização das sondas periodontals utilizadas em uma instituição de ensino superior de Maceió-AL. Int J Dent. 2010;9(3):120-7.

18. Tahim CM, Barbosa CS, Mota OML, Pereira SLS, Lima DLF, Carlos MX. Avaliação da padronização de sondas periodontais tipo Williams. Periodontia. 2007 Set;17(3):86-9.

19. dos Santos KM, Pinto SCS, Pochapski MT, Wambier DS, Pilatti GL, Santos FA. Molar furcation entrance and its relation to the width of curette blades used in periodontal mechanical therapy. Int J Dent Hyg. 2009 Nov;7(4):263-9. http://dx.doi.org/10.1111/j.1601-5037.2009.00371.x.

20. Maritato M, Orazi L, Laurito D, Formisano G, Serra E, Lollobrigida M, et al. Root surface alterations following manual and mechanical scaling: a comparative study. Int J Dent Hyg. 2018 Nov;16(4):553-8. http://dx.doi.org/10.1111/idh.12349.

\section{CONFLICTS OF INTERESTS}

The authors declare no conflicts of interest.

\section{*CORRESPONDING AUTHOR}

Elizangela Cruvinel Zuza, UFF - Universidade Federal Fluminense, Rua Dr. Silvio Henrique Braune, 22, Centro, 28625-650 Nova Friburgo - RJ, Brasil, e-mail: elizangelazuza@yahoo.com.br 